\title{
Influence of fertilizers, including biomodified ones, on the balance of nutrients in the soil and yield capacity in crop rotation
}

\author{
Galina Saidasheva ${ }^{1, *}$, Alevtina Kulikova ${ }^{2}$, Sergey Nikitin ${ }^{1}$ and Alexander Lashchenkov ${ }^{2}$ \\ ${ }^{1}$ Ulyanovsk Research Institute - Branch of Samara Federal Research Center of RAS, 433315 Ulyanovsk, Russia \\ ${ }^{2}$ Ulyanovsk State Agrarian University named after P. A. Stolypin, 432017 Ulyanovsk, Russia
}

\begin{abstract}
The article presents the results of studies on the influence of mineral, biomodified mineral fertilizers and BisolbiFit biologics on the balance of basic nutrients in soil under fallow crops. According to the results of correlation and regression analysis, the total removal (grain plus straw) of basic nutrients strongly depended on the level of grain yield. The increase in grain yield from 2.85 to 3.45 t/ha was accompanied by an increase in the total removal of nitrogen from 73.6 to $130.1 \mathrm{~kg} / \mathrm{ha}$, phosphorus - from 30.8 to $68.4 \mathrm{~kg} / \mathrm{ha}$, and potassium - from 41.6 to $74.0 \mathrm{~kg} / \mathrm{ha}$. The balance of basic nutrients depended not only on the grain yield, but also on the doses of fertilizers applied. For all variants of the experiment, the nitrogen balance was consistently reduced from -55.4 to $-22.1 \mathrm{~kg} / \mathrm{ha}$ as the yield increased from 2.85 to $3.45 \mathrm{t} / \mathrm{ha}$. The phosphorus balance decreased from -52.4 to $-30.8 \mathrm{~kg} / \mathrm{ha}$, and its negative balance increased from background 1 (zero) to background $3(1 / 2 \mathrm{NH} 4 \mathrm{NO} 3 \mathrm{~m})$. The balance of potassium, as well as the balance of nitrogen and phosphorus, was negative for all variants of the experiment, and decreased from -60.9 to $-40.0 \mathrm{~kg} / \mathrm{ha}$.
\end{abstract}

\section{Introduction}

Over the past 20 years, there has been a sharp decrease in the use of mineral fertilizers in all regions of the Russian Federation, which has led to a decrease in the yield and quality of agricultural products [1]. This results from a number of factors with the leading role played by the growth of prices for mineral fertilizers. Besides, an additional increase in yield does not always repay the use of fertilizers. One of the most important sources of increasing the efficiency of mineral fertilizers is represented with the use of biotechnologies that allow for the full realisation of the soil and climate potential of agro-landscape and the potential of agricultural crops [2-6]. Biologics have long been used for processing seeds and vegetating plants, and only recently it became possible to apply agronomically useful bacteria to the surface of mineral fertilizer granules. Russian scientists have developed and patented a microbial preparation and a method for biomodification of mineral fertilizers, which allows increasing the coefficient of assimilation of nutrients by plants from fertilizers by an average of 20-30 \% [7]. To modify the granules of mineral fertilizers, a dry form of BisolbiFit biologic is used. Its active substance is a strain of rhizospheric bacteria Bacillius Subtilis $H-13$.

In this connection, the research purpose consists in comparative study of the effectiveness of mineral and biomodified mineral fertilizers, as well as BisolbiFit biologic in the cultivation of fallow crops on leached black soil of the Middle Volga region.
The research was carried out on the experimental field of the Ulyanovsk State Agrarian University in 2013-2018 in the fallow crop rotation: fallow land winter wheat - spring wheat - barley - oats. The soil of the experimental field is leached heavy loam with a humus content of 6.43-6.62 \%, available phosphorus and potassium compounds (according to Chirikov) 214-228 and 101-117 mg/kg of soil, pH 6.3-6.8.

\section{Materials and methods}

The research objects include:

- nitrogen-phosphorus-potassium fertilizer (NPP 15:15:15), introduced as a near-sown water-soluble fertilizer with an equal NPK content of $15 \%$ and ammonium nitrate $\left(\mathrm{N}_{34}\right)$ as a background fertilizer, introduced for pre-sown cultivation;

- BisolbiFit microbiologic based on a strain of rhizospheric bacteria Bacillius Subtilis $H-13$. Bacteria have the ability to synthesize substances that inhibit the development of phytopathogenic fungi and bacteria, as well as substances that stimulate plant growth [8].

The experiment scheme consisted of 5 variants. Fertilizers were introduced to the rows during crop sowing:

1. Control without fertilizers;

2. BisolbiFit - pre-sowing treatment of seeds at a dose of 400-600 g/t;

3. NPK - NPPF at a dose of $15 \mathrm{~kg}$ of active substance per 1 ha;

\footnotetext{
Corresponding author: Galina_83@list.ru
} 
4. NPKm - treatment of NPPF granules with a biopreparation at a dose of $15 \mathrm{~kg}$ of active substance per 1 ha;

5.1/2 NPKm - treatment of NPPF granules with a biopreparation at a dose of $7.5 \mathrm{~kg}$ of active substance per 1 ha.

A dry form of the microbiologic was used to prepare biomodified fertilizers $\left(\mathrm{N}_{15} \mathrm{P}_{15} \mathrm{~K}_{15 \mathrm{~m}}, 1 / 2 \mathrm{~N}_{15} \mathrm{P}_{15} \mathrm{~K}_{15 \mathrm{~m}}, 1 / 2\right.$ $\mathrm{NH} 4 \mathrm{NO}_{\mathrm{m}}$ ). BisolbiFit was applied to mineral fertilizers on the day of their application at a dose of $4 \mathrm{~kg}$ per $1 \mathrm{ton}$ of fertilizers.

Pre-sowing treatment of seeds with BisolbiFit (dry form) was carried out 1-2 days before sowing. The preparation (at a dose of 400-600 grams per 1 hectare) was diluted in water at the rate of 10 liters of water per 1 ton of seeds and applied to the seeds, thoroughly mixed by hand until the drug was evenly distributed.

The effectiveness of mineral, biomineral fertilizers and biologics was evaluated on 3 backgrounds. The first remained as a control one (zero background); on the second background, pure ammonium nitrate was introduced at a dose of $40 \mathrm{~kg}$ (NH4NO3); on the third background, ammonium nitrate was introduced at a dose of $20 \mathrm{~kg}\left(1 / 2 \mathrm{NH} 4 \mathrm{NO} 3_{\mathrm{m}}\right)$, treated with BisolbiFit.

The registered area of plots is $100 \mathrm{~m}^{2}(4 \times 25)$, the repetition is threefold, and their location is randomized. Organization of field experiments, selection of soil and plant samples, observations and laboratory analyses were carried out according to the relevant state standards (GOSTs).

\section{Results and discussion}

In our research, calculation of nutrients balance on heavy-loamy soil was carried out taking into account the following sources of their input: mineral fertilizers and biologics, precipitation, seeds. Annual nitrogen input with atmospheric precipitation is peculiar of the foreststeppe $-10 \mathrm{~kg}$ of nitrogen; steppe $-4 \mathrm{~kg}$; forest area and the Carpathian region - $5 \mathrm{~kg}$ [9]. This inflow source is calculated only for nitrogen fertilizers, since the input of other elements with precipitation is insignificant. The input of nutritients from seeds is small as compared to other sources and is relevant only for the crops that have a high seeding rate. The calculations were based on the following indicators: the seeding rate and the content of nutrients in seeds.

The question of the contribution of non-symbiotic nitrogen fixers to the soil nitrogen balance is quite controversial. It is believed that on average, nitrogenfixing bacteria can accumulate $10-15 \mathrm{~kg}$ of nitrogen per 1 ha annually [10].

In the inflow items of the balance, the higher specific weight is made up by the input of nitrogen with fertilizers (16 kg of active substance per 1 ha and $7.5 \mathrm{~kg}$ of active substance per 1 ha), as well as the fixing of molecular nitrogen by microorganisms that are part of the biological product.

The removal of nutrients is the main cause of their losses. The outflow part took into account the removal of nutrients with the crop (grain plus straw), unproductive losses of nitrogen fertilizers. This item refers to losses only of nitrogen fertilizers, since they are characterized by different ways of unproductive losses in the gaseous state and as a result of leaching. The calculations are based on the average indicator of $10 \%$ on black soils.

Table 1 shows that the amount of alienated nitrogen with the yield of fallow crops varied much - from 73.6 to $130.1 \mathrm{~kg} / \mathrm{ha}$, which, first of all, was determined by the level of yield. The lowest removal of nitrogen was marked in the control variant and amounted to 73.6 $\mathrm{kg} / \mathrm{ha}$; the highest - in the variant with the use of full dose of the modified NPP fertilizer together with the introduction of a half-dose of modified ammonium nitrate for pre-sowing cultivation $(130.1 \mathrm{~kg} / \mathrm{ha})$.

Calculations show that the use of the studied fertilizers increased nitrogen removal by $8-57 \mathrm{~kg}$ in relation to the absolute control, which is explained by the higher crop yield for these variants.

The nitrogen balance in all variants of the experiment was negative and increased from $-22.1 \mathrm{~kg} / \mathrm{ha}$ (in the variant where the seeds were treated with BisolbiFit before sowing on background 2) to $-55.4 \mathrm{~kg} / \mathrm{ha}$ (when using a half-dose of the modified NPP fertilizer on background 3).

It should be noted that the introduction of the studied fertilizers on zero background increased the tension of the nitrogen balance, which averaged $-47.4 \mathrm{~kg} / \mathrm{ha}$ on the background. Meanwhile, the combined use of the NPP fertilizer and the biologics against the background of ammonium nitrate at a full dose in pure form contributed to a significant reduction in the balance tension to $-29.2 \mathrm{~kg} / \mathrm{ha}$.

Table 1. Dependence of nitrogen balance on the use of mineral fertilizers and biologics, $\mathrm{kg} / \mathrm{ha}$. Average for 2013-2018

\begin{tabular}{|c|c|c|c|c|c|}
\hline 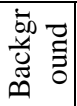 & $\begin{array}{c}\text { Varia } \\
\text { nt }\end{array}$ & Removal & Input & $\begin{array}{c}\text { Balance, } \\
+/-\end{array}$ & $\begin{array}{c}\text { Balance } \\
\text { intensity, \% }\end{array}$ \\
\hline \multirow{6}{*}{$\stackrel{0}{\stackrel{D}{N}}$} & 1. & 73.6 & 26.0 & -47.6 & 35.3 \\
\hline & 2. & 81.1 & 36.2 & -44.9 & 44.6 \\
\hline & 3. & 90.4 & 42.0 & -48.4 & 46.5 \\
\hline & 4. & 101.9 & 55.3 & -46.6 & 54.6 \\
\hline & 5. & 88.3 & 38.8 & -49.5 & 44.0 \\
\hline & \multicolumn{3}{|c|}{ Average of the background } & -47.4 & \\
\hline \multirow{6}{*}{ 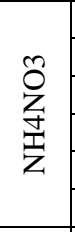 } & 1. & 83.8 & 60.0 & -23.9 & 71.6 \\
\hline & 2. & 94.3 & 72.2 & -22.1 & 76.6 \\
\hline & 3. & 105.7 & 76.0 & -29.7 & 80.3 \\
\hline & 4. & 122.9 & 92.4 & -30.6 & 75.2 \\
\hline & 5. & 114.7 & 75.0 & -39.7 & 65.4 \\
\hline & \multicolumn{3}{|c|}{ Average of the background } & -29.2 & \\
\hline \multirow{6}{*}{ 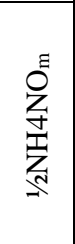 } & 1. & 82.8 & 47.8 & -35.0 & 57.7 \\
\hline & 2. & 94.8 & 61.0 & -33.9 & 64.3 \\
\hline & 3. & 106.3 & 57.5 & -48.8 & 54.1 \\
\hline & 4. & 130.1 & 76.7 & -53.4 & 59.0 \\
\hline & 5. & 118.1 & 62.7 & -55.4 & 53.1 \\
\hline & \multicolumn{3}{|c|}{ Average of the background } & -45.3 & \\
\hline
\end{tabular}

*1. Control; 2. BisolbiFit; 3. $\mathrm{N}_{15} \mathrm{P}_{15} \mathrm{~K}_{15}$;

4. $\mathrm{N}_{15} \mathrm{P}_{15} \mathrm{~K}_{15 \mathrm{~m} ;}$ 5. ${ }^{1 / 2} \mathrm{~N}_{15} \mathrm{P}_{15} \mathrm{~K}_{15 \mathrm{M}}$

Calculation of the balance in $\mathrm{kg} / \mathrm{ha}$ does not always make it possible to fully understand the degree of influence of crops on the state of soil. The balance intensity indicator provides a deeper understanding of 
the situation. It is expressed as the percentage ratio of elements entering the soil to their losses.

The value of the balance intensity shows the percentage of removed elements which are compensated by their input from various sources. The intensity can be less than $100 \%$ (deficit balance), equal to $100 \%$ (deficit-free balance), and more than $100 \%$ (positive balance) [11].

The intensity of the nitrogen balance increased on zero background from 43 to $62 \%$, on the background of NH4NO3 - from 74 to $89 \%$, and on the background of $1 / 2 \mathrm{NH}_{4 N O} 3_{\mathrm{m}}-$ from 59 to $75 \%$. The introduction of a half-dose of the modified NPP fertilizer reduced nitrogen recovery as compared to other variants due to the large removal from the final product. Thus, it becomes clear that only $43-89 \%$ of the element losses are compensated by input.

Unlike nitrogen, phosphorus does not have natural sources of replenishment in the soil. The removal of phosphorus from the crop is compensated only when applying phosphorus and organic fertilizers. Many authors believe that the introduction of a fertilizer system allows for a moderately negative balance of phosphorus, which will not change the level of soil fertility [12].

Table 2 shows that the removal of phosphorus with the alienated part of the crop, which varied from 30.8 to $68.4 \mathrm{~kg} / \mathrm{ha}$ is the main value in the outflow part of the balance. Alienation of phosphorus from cash crops was closely related to the grain yield, which increased when mineral, biomineral fertilizers and biologics were used for crop rotation. Introduction of pure ammonium nitrate or a half-dose of modified ammonium nitrate for presowing cultivation increased phosphorus alienation at crop cultivation.

The phosphorus balance was negative for all variants of the experiment and varied within the range of $-30.8--52.4 \mathrm{~kg} / \mathrm{ha}$. It should be noted that the negative phosphorus balance increased from zero background to the third background $\left(1 / 2 \mathrm{NH} 4 \mathrm{NO} 3_{\mathrm{m}}\right)--35.4 ;-44.2$; $-46.5 \mathrm{~kg} / \mathrm{ha}$, respectively.

As in the case of the above macronutrients, the removal of potassium from the soil was also determined by the yield of a fallow crop. The balance of potassium, as well as the balance of nitrogen and phosphorus, was negative for all variants of the experiment, and decreased from -60.9 to $-40.0 \mathrm{~kg} / \mathrm{ha}$. The use of a half-dose of the modified NPP fertilizer $\left(1 / 2 \mathrm{~N} 15 \mathrm{P} 15 \mathrm{~K} 15_{\mathrm{m}}\right)$ on the studied backgrounds (Background 1 - zero, Background 2 NH4NO3, Background $3-1 / 2 \mathrm{NH}_{4} \mathrm{NO} 3_{\mathrm{m}}$ ) reduced the recovery of potassium due to a large removal from the final product.

Grain yield is the main indicator in the evaluation of the studied methods of plant cultivation. It largely depends on the conditions of growing plants. In the process of growth and development, certain requirements are imposed on the conditions of the external environment, which are associated with the nature and intensity of the physiological and biochemical processes occurring in them.

The use of mineral fertilizers is one of the most effective and fast-acting factors that improve plant nutrition and increase grain yield. Over the last decade, the use of microbiological preparations is considered to be a promising direction, which, due to the additional involvement of the main elements of mineral nutrition in the agrocenosis, also contribute to increasing the grain productivity of the crop [13].

Table 2. Dependence of phosphorus and potassium balance on the use of mineral fertilizers and biologics, $\mathrm{kg} / \mathrm{ha}$. Average for 2013-2018

\begin{tabular}{|c|c|c|c|c|c|c|c|}
\hline \multirow{2}{*}{ 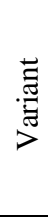 } & \multicolumn{2}{|c|}{ Removal } & 芯 & \multicolumn{2}{|c|}{ Balance, $+/-$} & \multicolumn{2}{|c|}{$\begin{array}{c}\text { Balance } \\
\text { intensity, } \\
\%\end{array}$} \\
\hline & ڤ̊ & 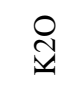 & 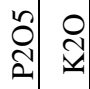 & 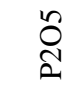 & $\underset{\mathscr{N}}{\mathscr{V}}$ & ڤి & $\stackrel{\mathscr{\Xi}}{\underline{y}}$ \\
\hline 1 & 30.8 & 41.6 & 0 & -30.8 & -41.6 & 0 & 0 \\
\hline 2 & 34.5 & 44.3 & 0 & -34.5 & -44.3 & 0 & 0 \\
\hline 3 & 50.5 & 55.6 & 16 & -37.5 & -40.0 & 32 & 28 \\
\hline 4 & 51.6 & 63.4 & 16 & -34.6 & -47.4 & 31 & 25 \\
\hline 5 & 47.0 & 55.7 & 7.5 & -39.5 & -48.2 & 16 & 13 \\
\hline \multicolumn{4}{|c|}{ Average of the background } & -35.4 & -44.3 & & \\
\hline 1 & 41.8 & 52.2 & 0 & -41.8 & -52.2 & 0 & 0 \\
\hline 2 & 42.3 & 58.7 & 0 & -42.3 & -58.7 & 0 & 0 \\
\hline 3 & 55.6 & 66.1 & 16 & -39.6 & -50.1 & 29 & 24 \\
\hline 4 & 63.4 & 73.4 & 16 & -47.4 & -57.4 & 25 & 22 \\
\hline 5 & 57.5 & 66.1 & 7.5 & -50.0 & -58.6 & 13 & 11 \\
\hline \multicolumn{4}{|c|}{ Average of the background } & -44.2 & -55.4 & & \\
\hline 1 & 41.1 & 52.4 & 0 & -41.1 & -52.4 & 0 & 0 \\
\hline 2 & 47.8 & 60.4 & 0 & -47.8 & -60.4 & 0 & 0 \\
\hline 3 & 57.0 & 68.0 & 16 & -41.0 & -52.0 & 28 & 23 \\
\hline 4 & 68.4 & 74.0 & 16 & -52.4 & -58.0 & 23 & 22 \\
\hline 5 & 57.8 & 68.4 & 7.5 & -50.3 & -60.9 & 13 & 11 \\
\hline \multicolumn{4}{|c|}{ Average of the background } & -46.5 & -56.8 & & \\
\hline
\end{tabular}

*1. Control; 2. BisolbiFit; 3. $\mathrm{N}_{15} \mathrm{P}_{15} \mathrm{~K}_{15} ; 4$. $\mathrm{N}_{15} \mathrm{P}_{15} \mathrm{~K}_{15} \mathrm{~m}$;

5. $1 / 2 \mathrm{~N}_{15} \mathrm{P}_{15} \mathrm{~K}_{15 \mathrm{~m}}$

The productivity of crop rotation in our studies was determined by the yield of individual crops, which depended not only on weather conditions of the growing season, but also on the type and doses of fertilizers used in the experiment (Table 3).

Winter wheat as one of the studied fallow grain crops, showed the maximum yield (3.88-4.80 t/ha). It is followed by spring wheat (2.68-3.31 t/ha) and spring barley (2.67-3.21 t/ha). The minimum productivity was demonstrated by oats, whose yield varied from 2.15 to $2.71 \mathrm{t} /$ ha over the period of 2016-2018.

Natural fertility of leached black soil provided a crop yield of $2.85 \mathrm{t} / \mathrm{ha}$. Pre-sowing treatment of seeds with BisolbiFit, introduction of the NPP fertilizer in pure and biomodified forms contributed to an increase in grain yield by $0.19-0.42 \mathrm{t} / \mathrm{ha}$ relative to the control variant.

After applying $40 \mathrm{~kg}$ of ammonium nitrate for presowing cultivation, the yield on the control variant made $3.07 \mathrm{t} / \mathrm{ha}$. The highest yield was noted on variant 4 $\left(\mathrm{N}_{15} \mathrm{P}_{15} \mathrm{~K}_{15 \mathrm{~m}}\right)-3.42 \mathrm{t} / \mathrm{ha}$.

The maximum yield of grain crops on average in this experiment was formed against the background, where ammonium nitrate at a dose of $20 \mathrm{~kg}$ of active substance was treated with BisolbiFit. The yield against this 
background increased from 3.01 to $3.45 \mathrm{t} / \mathrm{ha}$, the increase in control value made $6.0-15.0 \%$.

The best conditions for high yields (2013-2018) were formed on the variant with the use of the microbiologics together with the mineral fertilizer $\left(\mathrm{N}_{15} \mathrm{P}_{15} \mathrm{~K}_{15 \mathrm{~m}}\right)$. The increase on zero background made $15 \%$, on background 2 (NH4NO3) - $11.0 \%$, and on background $3(1 / 2$ $\left.\mathrm{NH} 4 \mathrm{NO}_{\mathrm{m}}\right)-15.0 \%$.

The use of biologics and the NPP fertilizer in its pure form ensured almost the same increase. This is explained by the fact that this dose provides plants with the necessary amount of nutrients, and the biologic contributes to their fuller use from fertilizer and mobilizes soil reserves.

Table 3. Yield of crop rotation when using mineral, biomodified mineral fertilizers and biologics, $\mathrm{t} / \mathrm{ha}$

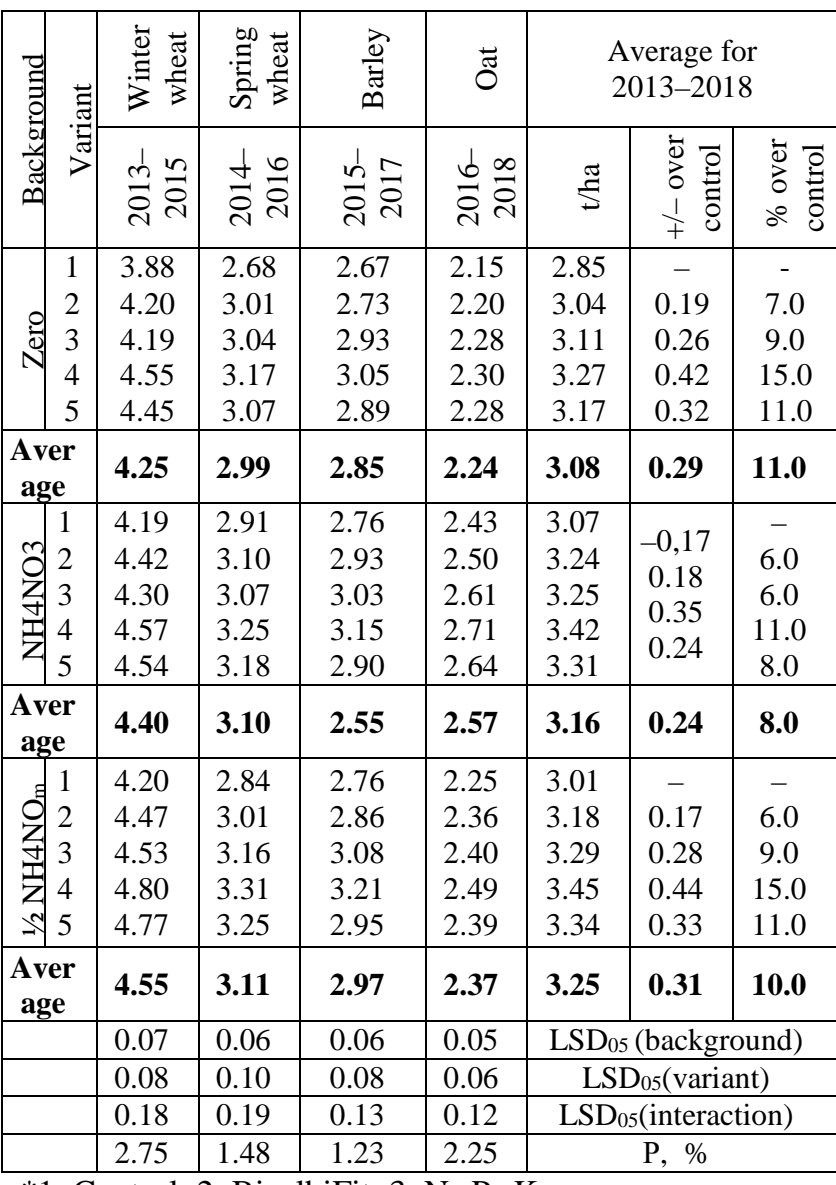

*1. Control; 2. BisolbiFit; 3. $\mathrm{N}_{15} \mathrm{P}_{15} \mathrm{~K}_{15}$;

4. $\mathrm{N}_{15} \mathrm{P}_{15} \mathrm{~K}_{15} \mathrm{~m} ;$ 5. $1 / 2 \mathrm{~N}_{15} \mathrm{P}_{15} \mathrm{~K}_{15 \mathrm{~m}}$

According to the results of correlation and regression analysis, the total removal (grain plus straw) of basic nutrients strongly depended on the level of fallow grain yield.

According to the obtained equations (Figure), the increase in grain yield from 2.85 to 3.45 t/ha was accompanied by an increase in the total removal (grain plus straw) of nitrogen from 73.6 to $130.1 \mathrm{~kg} / \mathrm{ha}$, phosphorus - from 30.8 to $68.4 \mathrm{~kg} / \mathrm{ha}$, and potassium from 41.6 to $74.0 \mathrm{~kg} / \mathrm{ha}$.
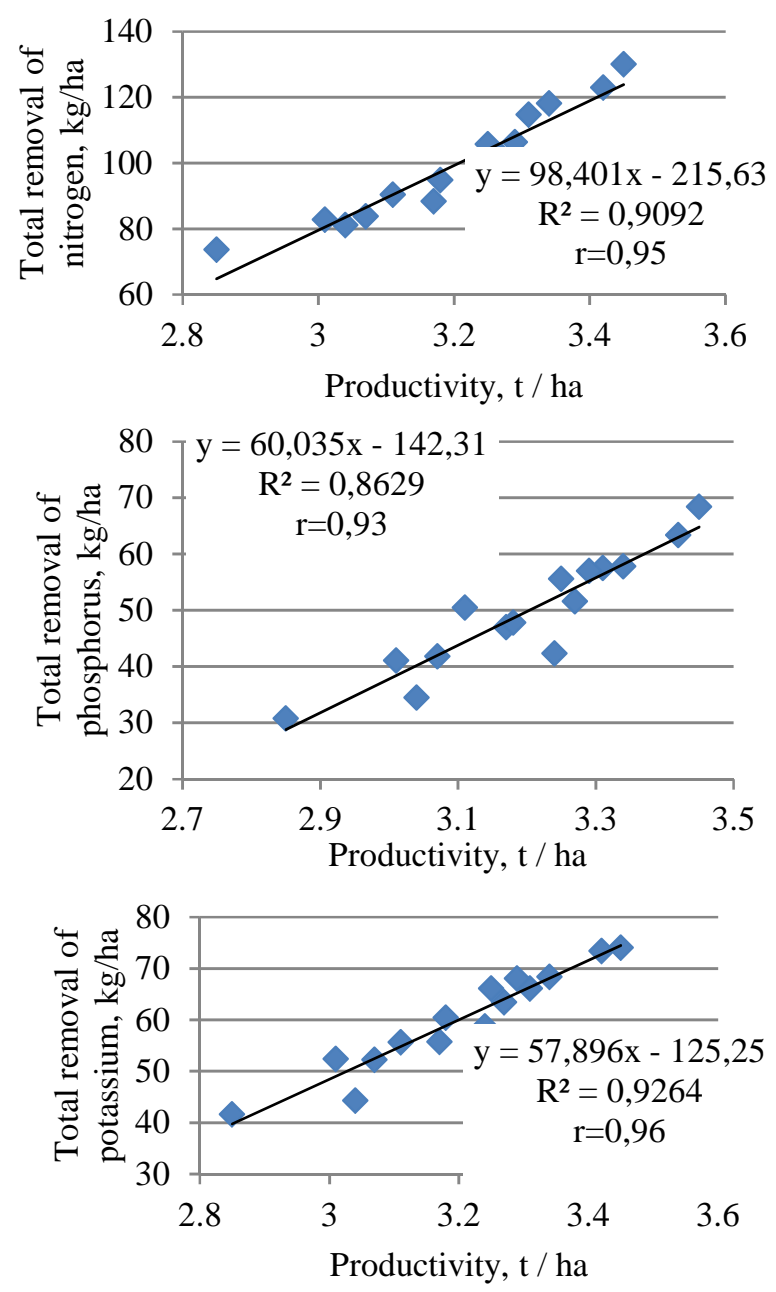

Fig. 1. Dependence of the total removal of nutrients on the level of fallow grain yields (2013-2018)

\section{Conclusion}

Thus, we can conclude that the full dose of the NPP fertilizer treated with BisolbiFit has positive effect on the productivity of crop rotation on all the studied backgrounds. The use of biologics and the NPP fertilizer in its pure form ensured almost the same increase on all the studied backgrounds.

However, the increase in grain yield from 2.85 to $3.45 \mathrm{t} / \mathrm{ha}$ was accompanied by an increase in the total removal of nitrogen from 73.6 to $130.1 \mathrm{~kg} / \mathrm{ha}$, phosphorus - from 30.8 to $68.4 \mathrm{~kg} / \mathrm{ha}$, and potassium from 41.6 to $74.0 \mathrm{~kg} / \mathrm{ha}$. The balance of basic nutrients depended not only on the grain yield, but also on the doses of fertilizers applied. For all variants of the experiment, the nitrogen balance was consistently reduced from -55.4 to $-22.1 \mathrm{~kg} / \mathrm{ha}$ as the yield increased from 2.85 to $3.45 \mathrm{t} / \mathrm{ha}$. The phosphorus balance decreased from -52.4 to $-30.8 \mathrm{~kg} / \mathrm{ha}$, and its negative balance increased from background 1to background 3 . The balance of potassium, as well as the balance of nitrogen and phosphorus, was negative for all variants of the experiment, and decreased from -60.9 to $-40.0 \mathrm{~kg} / \mathrm{ha}$. 


\section{References}

1. A.A. Zavalin, V.K. Chebotar, A.E. Kazakov, A.L. Tarasov, Efficiency of application of ammonium nitrate treated with a biological preparation for spring wheat, Bull. of the Russ. Acad. of Agricult. Sci., 1, 64-66 (2008)

2. S.N. Nikitin, G.V. Saidasheva, M.V. Petrov, Productivity of winter wheat at complex use of organic fertilizers with diatomite and biologics, Achievements of sci. and technol. in the AgroIndust. Complex, 31(4), 36-39 (2017)

3. A.A. Zavalin, V.K. Chebotar, A.G. Aritkin, V.V. Esin, Experience in application of biomineral fertilizers, Sci. and inform. Bull. World of Sulfur, N, P, K, 6, 27-30 (2011)

4. A.A. Zavalin, V.K. Chebotar, A.G. Aritkin, D.B. Smetov, Biologization of mineral fertilizers as a way to increase the efficiency of their use, Achievements of sci. and technol. in the AgroIndust. Complex, 09, 45-47 (2012)

5. V.B. Petrov, V.K. Chebotar, Microbiological preparations are the basic element of modern intensive agricultural technologies of crop production, Achievements of sci. and technol. in the Agro-Indust. Complex, 08, 11-14 (2011)

6. A.Kh. Kulikova, S.N. Nikitin, A.L. Toigildin, Biopreparations in the Spring wheat Fertilization system, Res. J. of Pharmac., Biolog. and Chem. Sci., 8(1), 1796-1800 (2017)

7. Russian patent no. 2241692 for the invention "Method for obtaining biofertilizers" (2004)

8. H. Junge, Strain selection, production and formulation of the biological plant vitality enhancing agent FZB24 Bacillus subtilis, Pflanzenschutz-Nachrichten Bayer, 1, 94-104 (2000)

9. V.B. Petrov, Microbiological preparations in the biologization of agriculture in Russia, Achievements of sci. and technol. in the AgroIndust. Complex, 10, 16 (2002)

10. A.Kh. Kulikova, G.V. Saidyasheva, A.N. Lascgenkov, S.N. Nemtsev, Influence of mineral and modified fertilizers on oat yield, BIO Web of Conf., 17, 00151 (2020)

11. N.S. Almetov, A.S. Kozyrev, Dynamics of fertility, productivity and balance of nutrients in arable soils of the Republic of Mari-El, Fertility, 5, 21-22 (2007)

12. V.G. Mineev, B. Garbarini, T. Mazur, Biological agriculture and mineral fertilizers (Kolos, Moscow, 1993)

13. I.O. Mityanin, D.B. Smetov, E.V. Dabakhov, Testing of the drug Bisolbifit on grain crops, Agrochem. Bull., 6, 35-37 (2011) 